\title{
FREEZING POTENTIALS AND GURRENTS IN POTASSIUM FLUORIDE SOLUTIONS AT CONSTANT GROWTH RATES
}

\author{
By T. O'D. HANLEY* and A. H. Weber \\ (Saint Louis University, Saint Louis, Missouri 63103, U.S.A.)
}

\begin{abstract}
The Workman-Reynolds effect was studied in the growth of ice on a monocrystalline seed, at constant growth rates and under steady-state conditions, from $\mathrm{KF}$ solutions at concentrations from $2 \times 10^{-5}$ to $10 \times 10^{-5}$ Normal. Freezing potentials increased with growth rate to a maximum of $12 \mathrm{~V}$ at ${ }_{11} .2 \mu \mathrm{m} / \mathrm{s}$. Discharge currents through a ${ }_{10}^{5} \Omega$ shunt generally increased with freezing rate until a maximum of $\mathrm{I} .5 \mu \mathrm{A}$ at $\mathrm{I} 1.2 \mu \mathrm{m} / \mathrm{s}$. The charge transfer decreased with growth rate to $200 \mu \mathrm{C}$ at $10.3 \mu \mathrm{m} / \mathrm{s}$ and then reached a maximum of $850 \mu \mathrm{C}$ at $11.2 \mu \mathrm{m} / \mathrm{s}$. Apparent diffusion coefficients of about $2 \times 10^{-3} \mathrm{~mm}^{2} / \mathrm{s}$ increased slowly with growth rate until a rapid increase began, apparently associated with interface breakdown. Distribution coefficients of the order of $\mathrm{IO}^{-3}$, calculated from a criterion for constitutional supercooling, increased with concentration. Parameters for LeFebre's model of the interface showed an interface thickness of about $6 \mathrm{~mm}$, an interface capacitance near one-half $\mathrm{pF} / \mathrm{mm}^{2}$, and an interface resistance of about $6 \times \mathrm{IO}^{4} \Omega / \mathrm{mm}^{2}$. Several empirical relations between these quantities were disclosed. Comparison with values obtained for $\mathrm{KCl}$ solutions with the same freezing cell shows that the KF solutions yielded higher values of freezing potential, charge transfer, and distribution coefficient, and lower values of diffusion coefficient, interface capacitance, and interface resistance.
\end{abstract}

RÉsumé. Potentials et courants de congélation dans solutions de fluorure de potassium congelées à taux constants de croissance. L'effet Workman-Reynolds a été étudié lors de la croissance de la glace, à des taux constants et pour des conditions à l'état permanent, sur un germe monocrystallin obtenu de solutions de KF à des concentrations variées entre $2 \times 10^{-5}$ et $10 \times 10^{-5} \mathrm{~mol} / 1$. D'une part les potentiels de congélation ont augmentés, en fonction du taux de croissance, jusqu'à un maximum de $12 \mathrm{~V}$ à $11,2 \mu \mathrm{m} / \mathrm{s}$. D'autre part les courants de décharge, à travers un circuit dérivé d'une résistance de $10^{5} \Omega$, ont augmentés jusqu'à une valeur de $\mathrm{I}, 5 \mu \mathrm{A}$, à $\mathrm{I} I, 2 \mu \mathrm{m} / \mathrm{s}$, en fonction du taux de congélation. En fonction du taux de croissance, le transfert de charge a d'abord diminué jusqu'à $200 \mu \mathrm{C}$ à $10,3 \mu \mathrm{m} / \mathrm{s}$ pour ensuite augmenter jusqu'à une valeur maximale égale à $850 \mu \mathrm{C}$ à I I, $2 \mu \mathrm{m} / \mathrm{s}$. Le coefficient apparent de diffusion augmente d'abord lentement en fonction du taux de croissance (valeur moyenne de $2 \times 10^{-3} \mathrm{~mm}^{2} / \mathrm{s}$ ), puis augmente très rapidement par le suite. Le coefficient de distribution, égal à environ $\mathrm{IO}^{-3}$, calculé à l'aide d'un critère de surfroidissement, augmente avec la concentration. Les paramètres du modèle de LeFebre donnent une interface d'environ $6 \mathrm{~mm}$, une capacitance d'un demi-pF $/ \mathrm{mm}^{2}$, et une résistance d'environ $6 \times 10^{4} \Omega / \mathrm{mm}^{2}$. Plusieurs relations empiriques reliant ces paramètres ont été determinées. La comparaison entre les valeurs obtenues pour des solutions de $\mathrm{KCl}$ et de $\mathrm{KF}$, en utilisant la même cellule de congélation, montre que les solutions, de KF donnent des valeurs plus grandes pour le potentiel de congélation, le transfert de charge, et le coefficient de distribution, et des valeurs plus faibles pour la capacitance et la résistance de l'interface.

Zusammenfassung. Gefrierspannungen und -ströme in Kaliumfluorid-Lösungen bei konstanten Wachstumsraten. Der Workman-Reynolds-Effekt wurde beim Wachstum von Eis um einen monokristallinen Kern bei konstanten Wachstumsraten und inter stetigen Bedingungen aus KF-Lösungen mit Konzentrationen von $2 \times 10^{-5}$ bis $10 \times 10^{-5}$ Normal untersucht. Die Gefrierspannung nahm mit der Wachstumsrate bis zu einem Höchstwert von $12 \mathrm{~V}$ bei $\mathrm{I}, 2 \mu \mathrm{m} / \mathrm{s}$ zu. Die Entladungsströme durch einen $\mathrm{IO}^{5} \Omega$-Nebenschluss nahmen im allgemeinen mit der Gefrierrate bis zu einem Höchstwert von $\mathrm{I}, 5 \mu \mathrm{A}$ bei $\mathrm{I}_{1,2} \mu \mathrm{m} / \mathrm{s}$ zu. Die Ladungsübertragung nahm mit der Wachstumsrate bis zu $200 \mu \mathrm{C}$ bei $10,3 \mu \mathrm{m} / \mathrm{s}$ ab und erreichte dann ein Maximum von $850 \mu \mathrm{C}$ bei $\mathrm{I} 1,2 \mu \mathrm{m} / \mathrm{s}$. Die scheinbaren Diffusionskoeffizienten von ungefähr $2 \times \mathrm{IO}^{-3} \mathrm{~mm}^{2} / \mathrm{s}$ stiegen zuerst langsam mit der Wachstumsrate an, bis ein schnelles Ansteigen begann, was anscheinend mit einem Zusammenbruch der Verwachsungsflächen zusammenhing. Die Verteilungskoeffizienten in der Grössenordnung $1^{-3}$, berechnet aus einem Kriterium für konstitutionelle Unterkühlung, nahmen mit der Konzentration zu. Die Parameter des Modells von LeFebre für die Verwachsung führten auf eine Dicke der Verwachsungszonen von ungefähr $6 \mathrm{~mm}$, eine Kapazität von ein Halb pF/mm² und einen Widerstand von ca. $6 \times \mathrm{IO}^{4} \Omega / \mathrm{mm}^{2}$. Mehrere empirische Beziehungen zwischen diesen Grössen wurden gefunden. Ein Vergleich mit Werten, die bei Verwendung von KCl-Lösungen in der gleichen Kältekammer erhalten worden waren, zeigt, dass bei den KF-Lösungen für Gefrierspannung, Ladungsübertragung und Verteilungskoeffizient grössere, für den Diffusionskoeffizienten, die Verwachsungskapazität und den Verwachsungswiderstand hingegen kleinere Werte auftreten.

\section{INTRODUGTION}

The Workman-Reynolds (1950) effect is the appearance of an electrical potential difference between the ice and the liquid during the freezing of dilute solutions of ionic solutes. While this effect was being studied, Brazilian scientists, following Costa Ribeiro

* Present address: Department of Mechanical Engineering, University of Ottawa, Ottawa, Ontario K I N $6 \mathrm{~N}_{5}$, Canada. 
(1950), were studying charge separation and electric currents produced during phase changes in dielectrics such as carnauba wax and pure water; this effect was called the Costa Ribeiro or thermodielectric effect.

For the most part Workman-Reynolds potentials or freezing potentials have been studied by means of a "freezing cup" placed on a cold heat sink. A thorough review of the results obtained by this method has been given by Gross (1968). The rate of freezing with this apparatus decreases sharply during the first few minutes of freezing. At approximately constant growth rates, freezing potentials have been studied by Levi and Milman (r966), Gross (1967), and Osterkamp and Weber (1970), and discharge currents through an external shunt have been studied by Pinatti and Mascarenhas (1967) during the freezing of pure water. In all of these experiments except those of Osterkamp and Weber, freezing began spontaneously at the metal base of the cell.

In the present investigation, growth was initiated from a monocrystalline seed oriented with its $c$-axis perpendicular to the direction of growth. Growth was allowed to proceed until a steady state had been reached before freezing potentials were measured; the steady state is an important feature of this study. The concentration at a small region in the liquid was monitored frequently while the interface was moving toward that region. Freezing potentials, discharge currents, and associated parameters were measured over the most interesting range of growth rates, at concentrations from $2 \times \mathrm{IO}^{-5}$ to $\mathrm{IO} \times \mathrm{IO}^{-5}$ Normal.

\section{THEORY}

Costa Ribeiro (1950) had enuntiated two laws for the thermodielectric effect, namely: (a) law of intensities: the discharge current is proportional to the rate of phase change; (b) law of charges: the total charge transfer is proportional to the total change of mass in the solid phase.

For the most part the study reported here used the equations already discussed by Osterkamp and Weber (1970). For the subsequent discussion it will be useful simply to list the equations. They fall readily into two groups.

Solute diffusion and distribution

Distribution and diffusion of the solute were studied using equations of Tiller and others (1953)

$$
\begin{gathered}
K^{\prime}=C_{\mathrm{s}}(\mathrm{o}) / C_{\mathrm{l}}(\mathrm{o}), \\
\ln \left[\frac{C_{\mathrm{l}}(x)}{C_{0}}-\mathrm{I}\right]=-\frac{R x}{D}+\ln \frac{\mathrm{I}-K}{K},
\end{gathered}
$$

and, as a criterion for constitutional supercooling,

$$
\frac{G}{R} \leqslant \frac{m C_{0}}{D}\left(\frac{\mathrm{I}-K}{K}\right)
$$

For potassium fluoride solutions at the low concentrations used in this work, the slope $m$ of the liquidus can be closely approximated by an empirical equation derived from the work of Karagunis and others (1930),

$$
m=3 \cdot 72-7 \cdot 435^{c}
$$

The symbols are used as follows:

$C_{0}$ initial concentration in the liquid far from the interface

$C_{1}(x)$ concentration in the liquid at distance $x$ from the interface

$C_{\mathrm{S}}(x)$ concentration in the solid at distance $x$ from the interface

$c$ solute concentration

(All concentrations are expressed here in moles/liter or, what is numerically the same for KF solutions, normality.) 
$D$ apparent coefficient of diffusion, in $\mathrm{mm}^{2} / \mathrm{s}$

$G$ temperature gradient in the liquid at the interface, in $\mathrm{deg} / \mathrm{mm}$

$K$ apparent coefficient of solute distribution, dimensionless

$K^{\prime}$ coefficient of solute distribution at the interface, dimensionless

$m$ slope of the liquidus for the solvent, in deg $1 / \mathrm{mol}$

$R$ rate of freezing, in $\mathrm{mm} / \mathrm{s}$

$x$ distance from the interface into either the liquid or the solid, in $\mathrm{mm}$.

\section{Interface model}

The model of the interface developed by LeFebre (1967) and modified for constant freezing rates by Osterkamp and Weber (1970) involves the following equations:

$$
\begin{gathered}
V_{\mathrm{i}}=R_{\mathrm{i}} I_{\mathrm{g}}{ }^{\prime} A R\left[\mathrm{I}-\exp \left(-t / R_{\mathrm{i}} C_{\mathrm{i}}\right)\right] ; \\
V_{\mathrm{m}}=R_{\mathrm{i}} I_{\mathrm{g}}{ }^{\prime} A R=R_{\mathrm{i}} I_{\mathrm{m}},
\end{gathered}
$$

$R_{\mathrm{i}}$ being thus related to $I_{\mathrm{m}}$, assuming constant current from the charge generator, for the case where the interface is shunted by a resistance much smaller than the resistance of the interface or of the ice;

$$
\begin{gathered}
V(q)=V_{\mathrm{i}} \exp (-a q), \\
C_{\mathrm{i}}=A \epsilon a, \\
K^{+}=\mathcal{N}_{\mathrm{s}}{ }^{+} / \mathcal{N}_{\mathrm{l}^{+}} \quad \text { and } \quad K^{-}=\mathcal{N}_{\mathrm{s}}-/ \mathcal{N}_{\mathrm{l}^{-}}, \\
K^{-}-K^{+}=I_{\mathrm{g}^{\prime}} / \mathcal{N}_{\mathrm{I}^{-}},
\end{gathered}
$$

this last equation assuming equal densities for the positive and negative ions near the interface.

The following further symbols have been introduced:

$A$ area of interface, in $\mathrm{mm}^{2}$

$a$ voltage decay constant, with dimensions of inverse length, $\mathrm{mm}^{-1}$

$C_{\mathrm{i}}$ interface capacitance, in $\mathrm{pF}$

$I_{\mathrm{g}}{ }^{\prime}$ parameter of the interface charge generator, in $\mathrm{C} / \mathrm{mm}^{3}$

$I_{\mathrm{m}}$ maximum of the discharge current, in A

$K^{+}$coefficient of cationic distribution, dimensionless

$K^{-}$coefficient of anionic distribution, dimensionless

$\mathcal{N}_{1^{ \pm}}$charge density of cations or anions in the liquid adjacent to the interface, in $\mathrm{C} / \mathrm{mm}^{3}$

$\mathcal{N}_{\mathrm{s}}{ }^{ \pm}$charge density of cations or anions in the solid adjacent to the interface, in $\mathrm{C} / \mathrm{mm}^{3}$

$q$ distance into the ice from the interface, in $\mathrm{mm}$

$R$ rate of freezing, in $\mathrm{mm} / \mathrm{s}$

$R_{\mathrm{i}}$ interface resistance, in $\Omega$

$t$ time, in $\mathrm{s}$

$V_{\mathrm{i}}$ potential difference across the interface, in $\mathrm{V}$

$V_{\mathrm{m}}$ maximum potential difference across the interface, in $\mathrm{V}$

$V(q)$ potential difference between the electrodes, in $\mathrm{V}$, when the electrode nearer the interface is at distance $q$ from the interface

$\epsilon$ dielectric constant of the ice, in $\mathrm{pF} / \mathrm{mm}$. The value $8.8 \times 10^{-7} \mathrm{pF} / \mathrm{mm}$ was used, following LeFebre ( 1967 ).

To these symbols should be added $q_{0}{ }^{\prime}$, the charge layer thickness in the ice, in $\mathrm{mm}$, defined as the distance $q$ in which $V(q)$ of Equation (7) decays to one-tenth of its initial value $V_{\mathrm{i}}$. 


\section{EXPERIMENTAL DETAILS}

For making solutions and for rinsing, water with a conductivity of $1 \mathrm{o}^{-4} \Omega^{-1} \mathrm{~m}^{-1}$ or lower was prepared by passing distilled water through three ion-exchange beds and a $0.6 \mu \mathrm{m}$ membrane filter.

The cell in which crystals were grown and the associated electrical apparatus are shown in Figure I. The seed crystal occupied this tube from the bottom to about $60 \mathrm{~mm}$ below the lower electrodes; the solution filled most of the rest of the tube. A crystal was grown by lowering the cell by a constant-speed motor and gear train into an alcohol bath maintained at $-50^{\circ} \mathrm{C} \pm \mathrm{I}$ deg by a deep-freeze unit. For each crystal grown, the interface was made to advance a distance of about $60 \mathrm{~mm}$ before useful measurements began; preliminary experiments had indicated that this achieved a steady state in diffusion, solute distribution, and freezing potentials. During growth the temperature in the solution at the lower electrodes was measured by the thermistor and a d.c. bridge, and the electrical conductance between the wires was measured by a Wayne-Kerr B64r Autobalance Bridge. From these two measurements it was possible to compute the concentration of the solution.

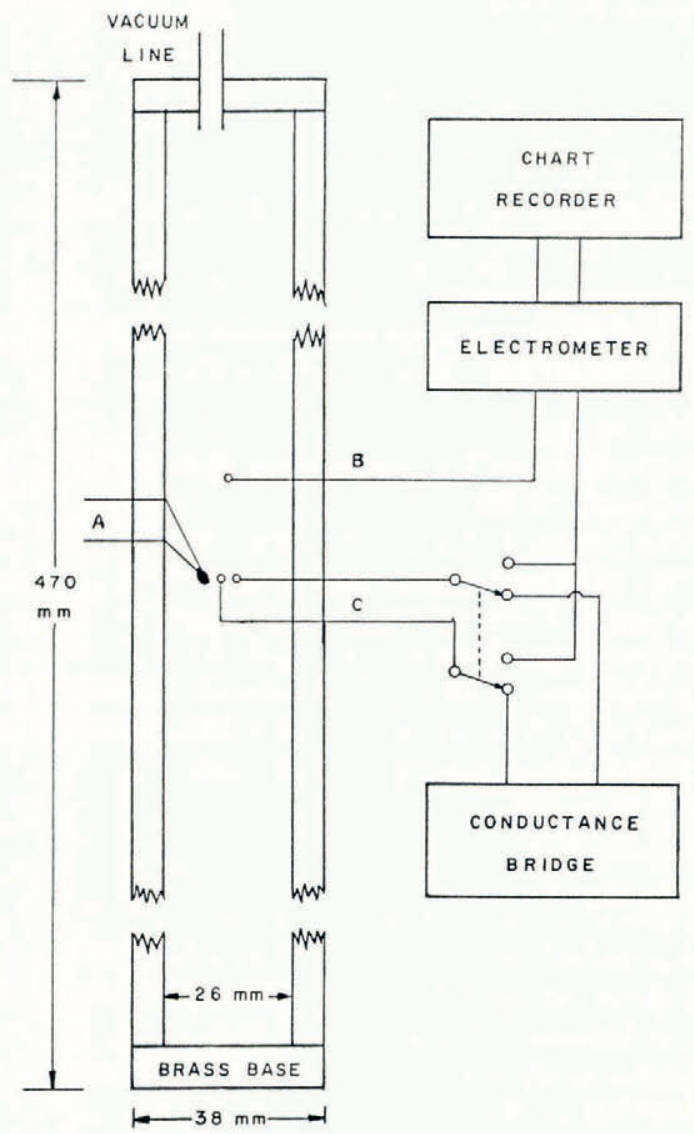

Fig. I. Schematic diagram of the cell used for growing crystals and the associated electrical apparatus. The tube and cap are of acrylic plastic ("Lucite"). A, wires from the thermistor to a resistance bridge. B, wire from the upper electrode to the electrometer. C, wires from the lower electrodes to a double-pole double-throw switch. The three electrodes are of platinum wire $0.36 \mathrm{~mm}$ in diameter; the two lower electrodes are placed parallel, $3 \mathrm{~mm}$ apart. 
When the interface neared and passed the lower electrodes, the conductance rose steadily to a maximum and then decreased quickly. When this happened the position of the doublepole switch was changed so that the potential difference between the upper and lower electrode was measured by a Keithley $6 \mathrm{IOR}$ electrometer. Growth was continued until this potential difference had decayed by an order of magnitude or more after the interface passed the upper electrode.

Discharge currents were measured by using the $10^{-5} \mathrm{~A}$ current range of the electrometer, which connected a $10^{5} \Omega$ shunt between the upper and lower electrodes.

A certain instability of temperature and conductance during growth were ascribed to convection, and attempts to reduce this by precooling with an ice jacket were failures. The most stable growth was obtained by using a heating coil surrounding the cell at a fixed position about $40 \mathrm{~mm}$ above the freezing bath. A gentle warmth in this heater sufficed for slower growth rates; at $11.2 \mu \mathrm{m} / \mathrm{s}$ and faster, a higher temperature gave best results. A disadvantage of using the heater was that, soon after the beginning of new growth, a cloud of fine bubbles appeared in the ice whenever the heater was employed. Ice grown after the heater was removed was clear again.

Simply evacuating the cell was not sufficient to remove dissolved gases, and pumping on the cell during crystal growth produced lower freezing potentials, probably because of disturbance caused by bubbles rising through the liquid. In order to remove dissolved gases as

TAble I. Mean values for the Maximum fReezing potential of the LiQUid With RESPECT TO THE ICE AND FOR THE MAXIMUM CURRENT AND THE TOTAL CHARGE TRANSFER THROUGH A IOO $\mathrm{k} \Omega$ SHUNT, FOR ICE GROWN FROM KF SOlUtions. ChARge PER UNIT VOLUME IS ALSO GIVEN, FOR A VOLUME OF $11.24 \times 10^{-6} \mathrm{~m}^{3}$ OF ICE BETWEEN THE LOWER AND UPPER ELECTRODES

\begin{tabular}{|c|c|c|c|c|c|c|c|}
\hline $\begin{array}{l}\text { Solution } \\
\text { normality }\end{array}$ & $\begin{array}{c}\text { Growth } \\
\text { rate } \\
\mu \mathrm{m} / \mathrm{s}\end{array}$ & $\begin{array}{l}\text { No. of } \\
\text { voltage } \\
\text { samples }\end{array}$ & $\begin{array}{c}\text { Maximum } \\
\text { freezing } \\
\text { potential } \\
\mathrm{V}\end{array}$ & $\begin{array}{c}\text { Maximum } \\
\text { current } \\
\mu \mathrm{A}\end{array}$ & $\begin{array}{l}\text { No. of } \\
\text { current } \\
\text { samples }\end{array}$ & $\begin{array}{c}\text { Charge } \\
\text { transfer } \\
\mu \mathrm{C}\end{array}$ & $\begin{array}{l}\text { Charge } \\
\text { density } \\
\mathrm{C} / \mathrm{m}^{3}\end{array}$ \\
\hline \multirow[t]{6}{*}{$2 \times 10^{-5}$} & $3 \cdot 3$ & I & 3.6 & - & - & - & - \\
\hline & $5 \cdot 5$ & 4 & 9.1 & 0.14 & 2 & 160 & 14 \\
\hline & 6.87 & 4 & 8.0 & o. 18 & 2 & 180 & $\mathrm{I} \hat{6}$ \\
\hline & $8.8^{\prime}$ & 4 & 7.6 & 0.19 & 2 & 120 & II \\
\hline & II 1.2 & 3 & 12.3 & 0.49 & 2 & 360 & $3^{2}$ \\
\hline & 14.0 & I & I 1.6 & - & - & - & - \\
\hline \multirow[t]{8}{*}{$3 \times 10^{-5}$} & $3 \cdot 3$ & 3 & $5 \cdot 5$ & o. 19 & I & 570 & $5 \mathrm{I}$ \\
\hline & 5.5 & 3 & 8.7 & 0.24 & I & 310 & 28 \\
\hline & 8.8 & 3 & 8.3 & 0.26 & I & 260 & 23 \\
\hline & $9 \cdot 9$ & 2 & IO.0 & 0.28 & 2 & 200 & 17 \\
\hline & 10.3 & 2 & $9 \cdot 5$ & 0.49 & 2 & 280 & 24 \\
\hline & I I .2 & 2 & 10.0 & $0.9 \mathrm{I}$ & 3 & 520 & 47 \\
\hline & 12.2 & 2 & $9 \cdot 3$ & $0.4^{6}$ & 2 & 310 & 28 \\
\hline & 14.0 & I & I 2.4 & 0.57 & 2 & 360 & $3^{2}$ \\
\hline \multirow[t]{10}{*}{$5 \times 10^{-5}$} & $3 \cdot 3$ & 2 & 6.2 & 0.20 & I & $4^{20}$ & 37 \\
\hline & $4 \cdot 3$ & 2 & 6.5 & $0.2 \mathrm{I}$ & I & 360 & $3^{2}$ \\
\hline & 5.5 & 3 & 7.2 & 0.23 & 2 & 270 & 24 \\
\hline & 6.87 & 3 & 8.7 & 0.23 & 2 & 210 & I9 \\
\hline & 8.8 & 3 & 10.2 & 0.27 & 2 & 190 & 17 \\
\hline & $9 \cdot 9$ & 2 & $9 \cdot 5$ & 0.33 & 2 & 220 & 19 \\
\hline & I0. 3 & 2 & I0.6 & 0.35 & 2 & 210 & 18 \\
\hline & I I .2 & 3 & I 2.4 & I.19 & 4 & 680 & 60 \\
\hline & 12.2 & 2 & 12.8 & $0.5^{8}$ & 2 & 360 & $3^{2}$ \\
\hline & 14.0 & 2 & I 1.8 & I.O4 & 2 & 6 ro & 54 \\
\hline \multirow[t]{6}{*}{$10 \times 10^{-5}$} & $3 \cdot 3$ & 2 & I.9 & 0.08 & I & 340 & 30 \\
\hline & $5 \cdot 5$ & 3 & $5 \cdot 3$ & o. 16 & 3 & 230 & 20 \\
\hline & 6.87 & 3 & 6.5 & O. 14 & 2 & 160 & 14 \\
\hline & 8.8 & 3 & 9.2 & 0.23 & 2 & 190 & 17 \\
\hline & II. 2 & 3 & IO. 2 & I. 25 & 2 & 840 & 75 \\
\hline & 14.0 & 3 & 8.4 & $0.9^{6}$ & I & 620 & 55 \\
\hline
\end{tabular}


much as possible from the solutions, the cell was left at the end of an experiment suspended in the bath at such a position that the ice would neither grow farther nor melt back. Then several hours before the next experiment the cell was raised slowly (to avoid cracking the ice if possible) to a position such that the ice would melt back until the interface was $60 \mathrm{~mm}$ below the lower electrodes. Pure water was added to the solution to compensate for that which would be drawn off by pumping, and a forepump was used to reduce the pressure to a few millibars for six hours or more while the upper part of the ice was melting.

\section{Results}

The long time required for each experiment prevented doing a sufficient number of trials for a statistical analysis at each concentration and growth rate. To give some idea of the reproducibility obtained, bars showing the spread of the data have been drawn for one concentration on many of the graphs.

After a steady state has been produced in the solute distribution, Equation (5) would predict a constant voltage across the interface. In practice, after rising to a plateau the voltage tended to rise or fall in an unpredictable fashion until, after the interface had passed the upper electrode, the voltage settled into a nearly exponential decay. The profile was similar to that described by Jindal and Tiller (I972) for $\mathrm{NH}_{4} \mathrm{I}$ solutions grown on a mercury substrate, yet growth and substrate conditions are quite different in the present case. Growth was terminated when the decaying voltage had fallen to one-tenth or less of its value at the beginning of the decay.

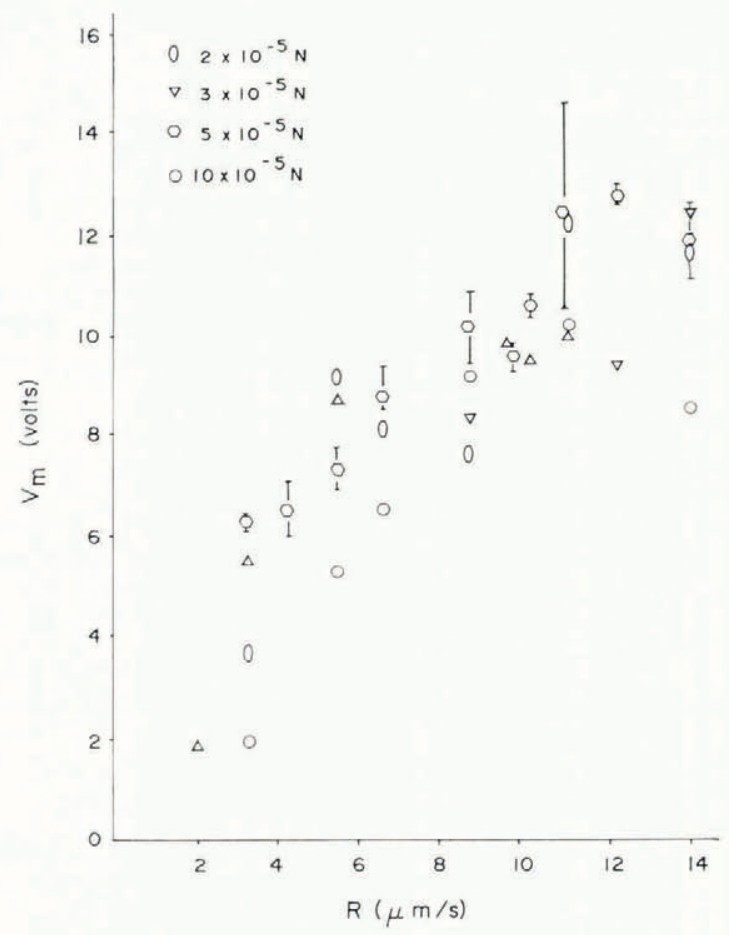

Fig. 2. Plot of maximum freezing potential $V_{\mathrm{m}}$ versus growth rate $R$. Vertical bars on points for $5 \times 10^{-5} \mathcal{N o r m a l}_{\text {represent }}$ the spread of the data. 
Whatever profile the voltage described, its maximum value for each experiment was recorded as $V_{\mathrm{m}}$. Mean values of these maximum freezing potentials for each growth rate and each concentration are shown in Table I and Figure 2.

A more regular pattern appeared when discharge currents through a ${ }^{1} 0^{5} \Omega$ shunt were observed. As the interface began to pass the lower electrodes, the current would rise quickly (in 2 to ro min, depending on the growth rate) to a maximum and then decrease approximately exponentially until the interface reached the upper electrode. Table I shows mean values obtained for these maxima, and also for the total charge transfer obtained by integrating with respect to time (using the trapezoidal rule) the current measured while the interface moved from the lower to the upper electrode. An average charge density has also been tabulated.

Values for the apparent coefficients of diffusion and of distribution are listed in Table II, and the apparent coefficients of diffusion at slower growth rates are displayed in Figure 3 .

Values for the interface parameters of LeFebre's ( 1967 ) model have been calculated from Equations (6), (7), (8), and (I0) and the results are shown in Table III. The decay constant $a$, the interface thickness $q_{0}{ }^{\prime}$, and the interface capacitance $C_{\mathrm{s}}$ are interdependent. They show much fluctuation for all concentrations tested; an overall pattern can be seen by computing a mean value for all concentrations at each growth rate. The results for interface thickness are shown in Figure 4 .

\begin{tabular}{|c|c|c|c|c|}
\hline $\begin{array}{c}\text { Solution } \\
\text { normality }\end{array}$ & $\begin{array}{c}\begin{array}{c}\text { Growth } \\
\text { rate }\end{array} \\
\mu \mathrm{m} / \mathrm{s}\end{array}$ & $\begin{array}{c}\text { No. of } \\
\text { samples }\end{array}$ & $\begin{array}{c}\text { Apparent } \\
\text { diffusion } \\
\text { coefficient } \\
\mathrm{IO}^{3} \mathrm{D} \\
\mathrm{mm}^{2} / \mathrm{s}\end{array}$ & $\begin{array}{c}\text { Apparent } \\
\text { distribution } \\
\text { coefficient } \\
K\end{array}$ \\
\hline $2 \times 10^{-5}$ & $\begin{array}{l}3 \cdot 3 \\
5.5 \\
6.87 \\
8.8 \\
11.2 \\
14.0\end{array}$ & $\begin{array}{l}\text { I } \\
5 \\
7 \\
7 \\
3 \\
1\end{array}$ & $\begin{array}{r}\text { г. } 8 \\
1.4 \\
\text { г. } \\
5.0 \\
34.6 \\
38.6\end{array}$ & $\begin{array}{l}0.04 \\
0.02 \\
0.07 \\
0.24 \\
0.59 \\
0.72\end{array}$ \\
\hline $3 \times 10^{-5}$ & $\begin{array}{r}3.3 \\
5.5 \\
8.8 \\
9.9 \\
10.3 \\
\text { I } 1.2 \\
12.2 \\
\text { I } 4.0\end{array}$ & $\begin{array}{l}4 \\
4 \\
3 \\
4 \\
4 \\
5 \\
4 \\
3\end{array}$ & $\begin{array}{r}1.5 \\
1.7 \\
3.3 \\
3.3 \\
4.4 \\
6.3 \\
16.3 \\
86.0\end{array}$ & $\begin{array}{l}0.04 \\
0.05 \\
0.14 \\
0.21 \\
0.30 \\
0.54 \\
0.62 \\
0.83\end{array}$ \\
\hline $5 \times 10^{-5}$ & $\begin{array}{c}3.3 \\
4.3 \\
5.5 \\
6.87 \\
8.8 \\
9.9 \\
10.3 \\
11.2 \\
12.2 \\
14.0\end{array}$ & $\begin{array}{l}3 \\
3 \\
5 \\
5 \\
4 \\
4 \\
4 \\
6 \\
4 \\
3\end{array}$ & $\begin{array}{r}\text { I.O } \\
\text { I.3 } \\
1.5 \\
1.4 \\
2.8 \\
2.7 \\
3.4 \\
8.3 \\
11.9 \\
172\end{array}$ & $\begin{array}{l}0.02 \\
0.04 \\
0.05 \\
0.08 \\
0.11 \\
0.17 \\
0.19 \\
0.60 \\
0.64 \\
0.77\end{array}$ \\
\hline $10 \times 10^{-5}$ & $\begin{array}{l}3.3 \\
5 \cdot 5 \\
6.87 \\
8.8 \\
\text { I } 1.2 \\
14.0\end{array}$ & $\begin{array}{l}3 \\
6 \\
5 \\
5 \\
5 \\
4\end{array}$ & $\begin{array}{r}1.1 \\
1.7 \\
1.7 \\
2.6 \\
19.2 \\
220\end{array}$ & $\begin{array}{l}0.04 \\
0.05 \\
0.10 \\
0.20 \\
0.72 \\
0.73\end{array}$ \\
\hline
\end{tabular}




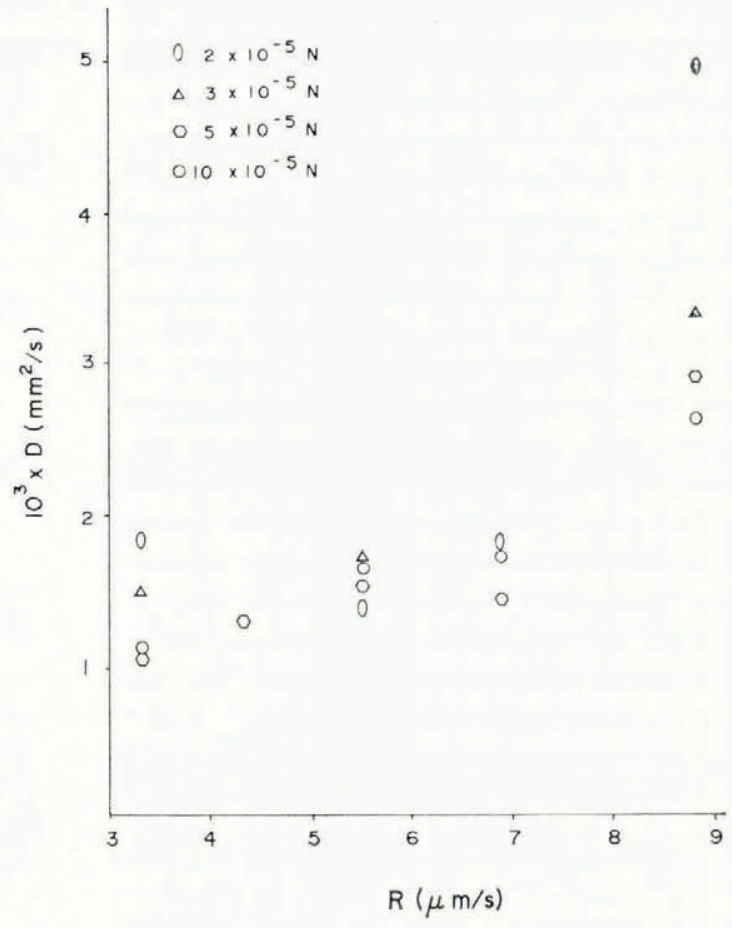

Fig. 3. Plot of apparent diffusion coefficient $D$ versus growth rate $R$, shown only for $R$ less than $9 \mu \mathrm{m} / \mathrm{s}$.

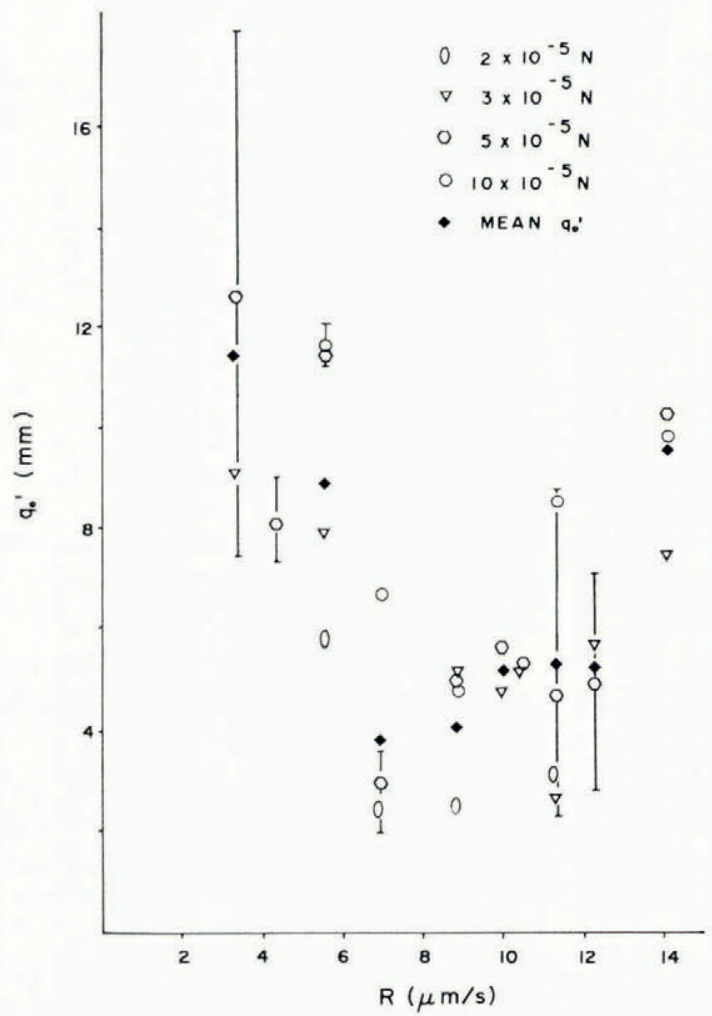

Fig. 4. Plot of interface thickness $q_{0}^{\prime}$ versus growth rate $R$. For each growth rate the mean over all concentrations studied has also been plotted. Vertical bars on points for $5 \times \mathrm{IO}^{-5}$ Normal solutions represent the spread of the data. 
TABle III. Mean values for the thickness, CaPACitance, And generator PARAMETER OF THE INTERFACE AND FOR THE IONIC SEPARATION PARAMETER IN THE LEFEBRE MODEL FOR THE WATER-ICE INTERFACE IN KF SOLUTIONS AT CONSTANT GROWTH RATES. THE AREA OF THE INTERFACE WAS $531 \mathrm{~mm}^{2}$

\begin{tabular}{|c|c|c|c|c|c|c|}
\hline $\begin{array}{c}\text { Solution } \\
\text { normality }\end{array}$ & $\begin{array}{c}\text { Growth } \\
\text { rate } \\
\mu \mathrm{m} / \mathrm{s}\end{array}$ & $\begin{array}{l}\text { No. of } \\
\text { samples }\end{array}$ & $\begin{array}{c}\text { Interface } \\
\text { thickness } \\
q_{\mathrm{o}}^{\prime} \\
\mathrm{mm}\end{array}$ & $\begin{array}{c}\text { Interface } \\
\text { capacitance } \\
C_{\mathrm{s}} \text { per unit } \\
\text { area } \\
\mathrm{pF} / \mathrm{mm}^{2}\end{array}$ & $\begin{array}{c}\text { Charge } \\
\text { generator } \\
\text { parameter } \\
I_{\mathrm{g}}^{\prime} \\
\mathrm{C} / \mathrm{m}^{3}\end{array}$ & $\begin{array}{c}\text { Ionic } \\
\text { separation } \\
\left(K^{-}-K^{+}\right) \\
\times 10^{3}\end{array}$ \\
\hline $2 \times 10^{-5}$ & $\begin{array}{c}5.5 \\
6.87 \\
8.8 \\
11.2\end{array}$ & $\begin{array}{l}4 \\
4 \\
3 \\
2\end{array}$ & $\begin{array}{l}5.8 \\
2.4 \\
2.1 \\
3.2\end{array}$ & $\begin{array}{l}0.39 \\
0.85 \\
1.06 \\
0.63\end{array}$ & $\begin{array}{l}47 \\
51 \\
41 \\
82\end{array}$ & $\begin{array}{r}0.4 \\
1.0 \\
6.1 \\
24.8\end{array}$ \\
\hline $3 \times 10^{-5}$ & $\begin{array}{r}3.3 \\
5.5 \\
8.8 \\
9.9 \\
10.3 \\
11.2 \\
12.2 \\
14.0\end{array}$ & $\begin{array}{l}1 \\
3 \\
2 \\
2 \\
2 \\
2 \\
2 \\
2 \\
1\end{array}$ & $\begin{array}{l}9 \cdot 1 \\
7 \cdot 9 \\
5 \cdot 2 \\
4 \cdot 9 \\
5 \cdot 3 \\
2 \cdot 4 \\
5 \cdot 7 \\
7 \cdot 4\end{array}$ & $\begin{array}{l}0.22 \\
0.28 \\
0.43 \\
0.42 \\
0.38 \\
0.85 \\
0.36 \\
0.27\end{array}$ & $\begin{array}{r}108 \\
83 \\
56 \\
52 \\
90 \\
172 \\
72 \\
94\end{array}$ & $\begin{array}{r}1.2 \\
1.3 \\
2.6 \\
5.3 \\
10.6 \\
29.6 \\
14.1 \\
26.2\end{array}$ \\
\hline $5 \times 10^{-5}$ & $\begin{array}{c}3.3 \\
4.3 \\
5.5 \\
6.87 \\
8.8 \\
9.9 \\
10.3 \\
11.2 \\
12.2 \\
14.0\end{array}$ & $\begin{array}{l}2 \\
2 \\
3 \\
3 \\
3 \\
2 \\
2 \\
3 \\
2 \\
2\end{array}$ & $\begin{array}{r}12.6 \\
8.2 \\
\text { I1 } .5 \\
3.0 \\
5.0 \\
5.7 \\
5.3 \\
4.8 \\
5.0 \\
10.4\end{array}$ & $\begin{array}{l}0.19 \\
0.25 \\
0.18 \\
0.74 \\
0.40 \\
0.36 \\
0.38 \\
0.5^{8} \\
0.5^{1} \\
0.20\end{array}$ & $\begin{array}{r}116 \\
91 \\
78 \\
64 \\
57 \\
63 \\
64 \\
230 \\
90 \\
151\end{array}$ & $\begin{array}{r}0.7 \\
0.7 \\
0.8 \\
1.1 \\
1.4 \\
2.9 \\
2.0 \\
30.8 \\
11.4 \\
23.4\end{array}$ \\
\hline $10 \times 10^{-5}$ & $\begin{array}{l}5.5 \\
6.87 \\
8.8 \\
11.2 \\
14.0\end{array}$ & $\begin{array}{l}3 \\
3 \\
2 \\
3 \\
3\end{array}$ & $\begin{array}{r}\text { 1 } .6 \\
6.6 \\
4.9 \\
8.6 \\
9.8\end{array}$ & $\begin{array}{l}0.18 \\
0.31 \\
0.43 \\
0.28 \\
0.21\end{array}$ & $\begin{array}{r}56 \\
39 \\
49 \\
211 \\
128\end{array}$ & $\begin{array}{r}0.4 \\
0.5 \\
0.7 \\
15.7 \\
9.7\end{array}$ \\
\hline
\end{tabular}

\section{Discussion}

(a) Voltage, current, and charge

The dependence of freezing potential on growth rate is similar to that reported for $\mathrm{KCl}$ solutions by Osterkamp and Weber (1970), although in the present case voltages were generally higher and the highest potential occurred at a faster freezing rate. The voltages of Table I are also similar to those obtained by Gross ( 1967 ) in his constant-rate study of KF solutions.

The behaviour of the current, shown in Figure 5, can be interpreted as a rise to a maximum near II $\mu \mathrm{m} / \mathrm{s}$ followed by a sudden drop and a subsequent new rise as the freezing rate is increased. Such a pattern resembles that reported for cesium fluoride solutions by Gross (1965), who reported similar results for potassium fluoride solutions. He did not measure freezing currents at constant freezing rates, however. It appears that the present paper is the first to report freezing currents measured during growth from ionic solutions at constant rates of freezing.

Alternatively, Figure 5 allows interpretation as a monotonic increase with growth rate except for a spike near II $\mu \mathrm{m} / \mathrm{s}$. This latter view seems more in accord with the behaviour of the charge transfer shown in Figure 6. The unusual values at $11.2 \mu \mathrm{m} / \mathrm{s}$ will receive further discussion near the end of this paper.

Costa Ribeiro's (1950) law of currents seems to predict a straight line in Figure 5; his law of charges seems to predict a horizontal straight line in Figure 6, since for each experiment with our cell the same volume of ice is formed between the lower and upper electrodes. The 


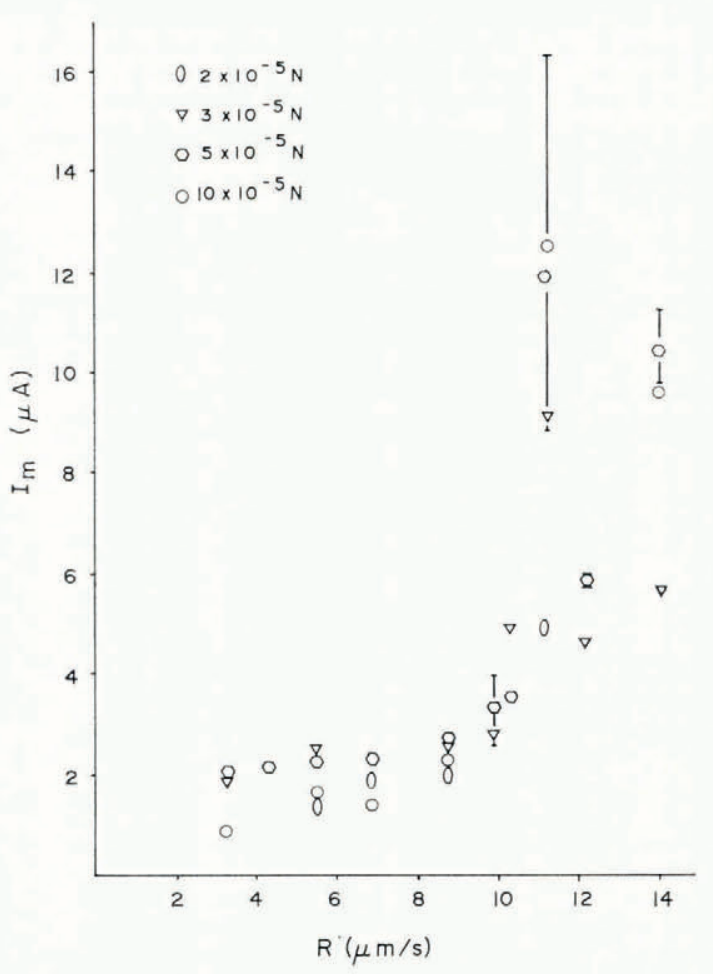

Fig. 5. Plot of maximum discharge current $I_{\mathrm{m}}$ through a $100 \mathrm{k} \Omega$ shunt, versus growth rate $R$. The vertical bars shown (where the spread is large enough) for $5 \times 1 \mathrm{O}^{-5}$ Normal represent the spread of the data.

very different results reported here may be due to the different growth conditions or to the greater complication in aqueous solutions than in the covalent compounds for which Costa Ribeiro's laws were primarily formulated.

Figure 7 shows a linear relation between the charge transfer $Q$ and the ratio of current to freezing rate, $I_{\mathrm{m}} / R$; the least-squares fitted line drawn in the figure has a slope of $7.2 \mathrm{~mm}$. Since $Q$ represents an integration over time of the discharge current, this $7.2 \mathrm{~mm}$ must be a characteristic distance $z$ such that the product of a mean time interval $z / R$ with the maximum current $I_{\mathrm{m}}$ is equal to $Q$. What is remarkable is the constancy of $z$ over the concentrations and growth rates studied.

\section{(b) Diffusion and distribution of solute}

Using Pohl's ( 1954) solution of the diffusion equation, which afforded a calculation of the distribution coefficient from both the slope and the intercept, Gross (1967) obtained values on the order of $\mathrm{IO}^{-3}$ or $\mathrm{IO}^{-4}$ from the slopes and $\mathrm{IO}^{-1}$ or $\mathrm{IO}^{-2}$ from the intercepts. The values for $K$ shown in Table II, calculated from intercepts by Equation (2), are comparable to Gross's intercept values, but values closer to $1^{-4}$ are to be expected (Gross, 1968). It should be noted that after the long time needed to reach the steady state, Pohl's solution for the diffusion equation becomes equivalent to Equation (2).

Another means of calculating distribution coefficients is offered by Equation (3) provided that the onset of constitutional supercooling can be determined. Constitutional supercooling favors a breakdown of the interface to a cellular or a dendritic form, which leads to solute 


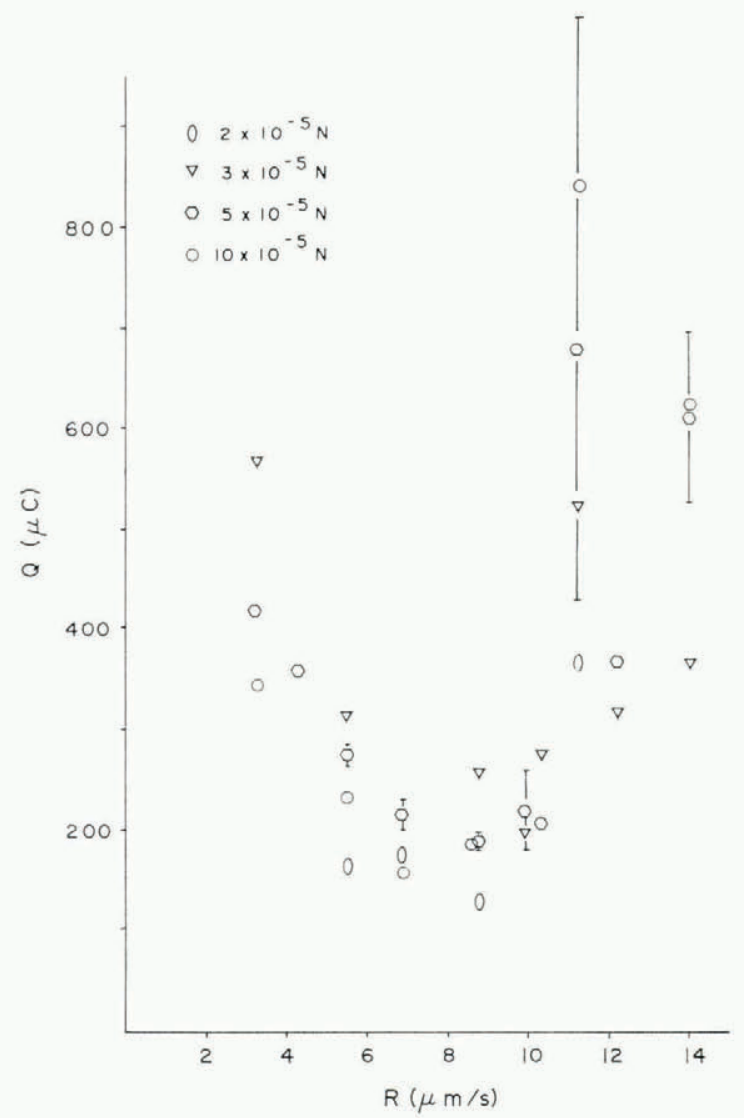

Fig. 6. Plot of total charge transfer $Q$ through a $100 k \Omega$ shunt versus growth rate $R$. Vertical bars on points for $5 \times 10^{-5}$ Normal represent the spread of the data.

inclusion between the cells. This causes an increase in the apparent coefficients of diffusion and distribution. If, following this reasoning, I I.2 $\mu \mathrm{m} / \mathrm{s}$ is chosen as the slowest freezing rate at which constitutional supercooling appears, the equality in Equation (3) yields the values listed in Table IV. A straight line fitted to the points by the method of least squares yields the relation

$$
K=53.47 C-3.98 \times 10^{-4}
$$

for the distribution coefficient $K$ (dimensionless) and the solute contration $C$ (in $\mathrm{mol} / \mathrm{l}$ ). It should be noted that this equation is based on measurements made only over the concentration range from $2 \times \mathrm{IO}^{-5}$ to $\mathrm{IO} \times \mathrm{IO}^{-5} \mathrm{~mol} / \mathrm{l}$.

If a linear dependence on growth rate, at least for the higher concentrations, is assumed for the apparent coefficient of diffusion at slower growth rates (Fig. 3), extrapolation to zero growth rate yields an intercept close to the limiting value $D_{0}=0.80 \times \mathrm{IO}^{-9} \mathrm{~m}^{2} / \mathrm{s}$ cited for $\mathrm{KF}$ solutions by Gross (1968).

\section{(c) Parameters of LeFebre's model}

Values for the interface thickness $q_{0}^{\prime}$ (Table III) are larger by as much as an order of magnitude than the I.o $\mathrm{mm}$ found by LeFebre (1967). It should be recalled that his growth conditions differ in many ways from ours, notably in that this freezing rate was initially quite 


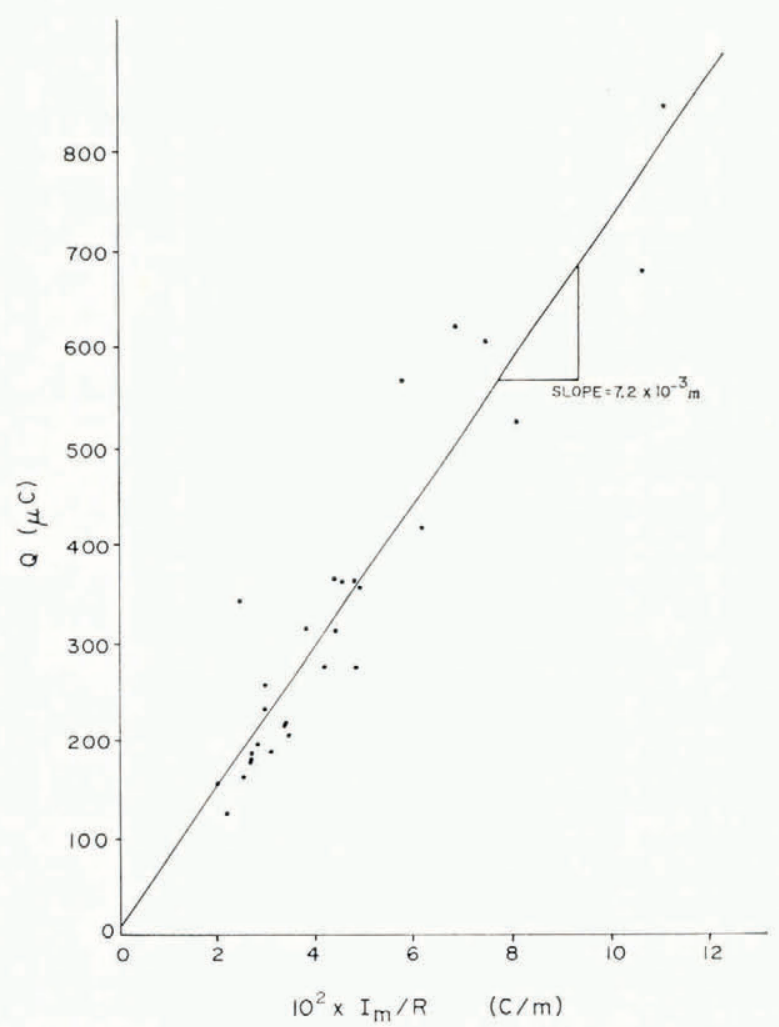

Fig. 7. Charge transfer $Q$ versus the ratio of maximum discharge current $I_{\mathrm{m}}$ to freezing rate $R$.

\begin{tabular}{|c|c|c|c|c|}
\hline LUTIONS AS & GALCULATED & $\begin{array}{l}\text { FROM THE } \\
\text { SUPERCOO }\end{array}$ & DITION FOR & STITUTIONAL \\
\hline $\begin{array}{c}\text { Nominal } \\
\text { bulk } \\
\text { normality } \\
C_{0}\end{array}$ & $\begin{array}{c}\text { Measured } \\
\text { bulk } \\
\text { normality } \\
\times \mathrm{IO}^{5}\end{array}$ & $\begin{array}{l}\text { No. of } \\
\text { samples }\end{array}$ & $\begin{array}{c}\text { Temperature } \\
\text { gradient } \\
G \\
\mathrm{deg} / \mathrm{mm}\end{array}$ & $\begin{array}{c}\text { Distribution } \\
\text { coefficient } \\
\mathrm{IO}^{3} \times K\end{array}$ \\
\hline $2 \times 10^{-5}$ & 2.02 & 3 & 1.22 & 0.9 \\
\hline $3 \times 10^{-5}$ & 3.17 & 5 & I. 34 & I. 2 \\
\hline $5 \times 10^{-5}$ & 5.01 & 6 & 1.27 & $2 . I$ \\
\hline $10 \times 10^{-5}$ & 9.90 & 5 & 1.08 & $5 \cdot 0$ \\
\hline
\end{tabular}

fast and then decreased with time. The values of $q_{0}{ }^{\prime}$ are computed from the time required for the freezing potential to decay to one-tenth of the value it had when the interface passed the upper electrode. For KF solutions LeFebre measured a time interval of about one minute; the corresponding time intervals for our experiments varied from five minutes to one hour, depending on the growth rate. The difference in values for the interface thickness was most likely due to two factors: (I) the freezing rate, which in our work was typically many times slower, and (2) the cell geometry, especially the shape of the electrodes and the distance between them.

The arithmetic mean of the values shown for $q_{0}{ }^{\prime}$ is $6.5 \mathrm{~mm}$. This is similar to the characteristic distance $z=7.2 \mathrm{~mm}$ which was found from current measurements (Fig. 7). From 
Figure 8 it can be seen that the ratio $Q / q_{0}{ }^{\prime}$ is approximately constant but does increase slowly with growth rate, except for an anomaly near II.2 $\mu \mathrm{m} / \mathrm{s}$. Such a correlation suggests that there is a connection between the voltage-related distance $q_{0}{ }^{\prime}$ and the current-related distance $z$. This supports the large values found for the boundary layer in our work. It also suggests that $q_{0}{ }^{\prime}$ has a dependence on electrode separation of the same order as that of $Q$.

Inversely proportional to $q_{0}{ }^{\prime}$ is the decay parameter $a$; its small value and the smaller area of the interface in our cell account for the lower values of the interface capacitance in Table III as compared with LeFebre's value of 2 ooo $\mathrm{pF}$.

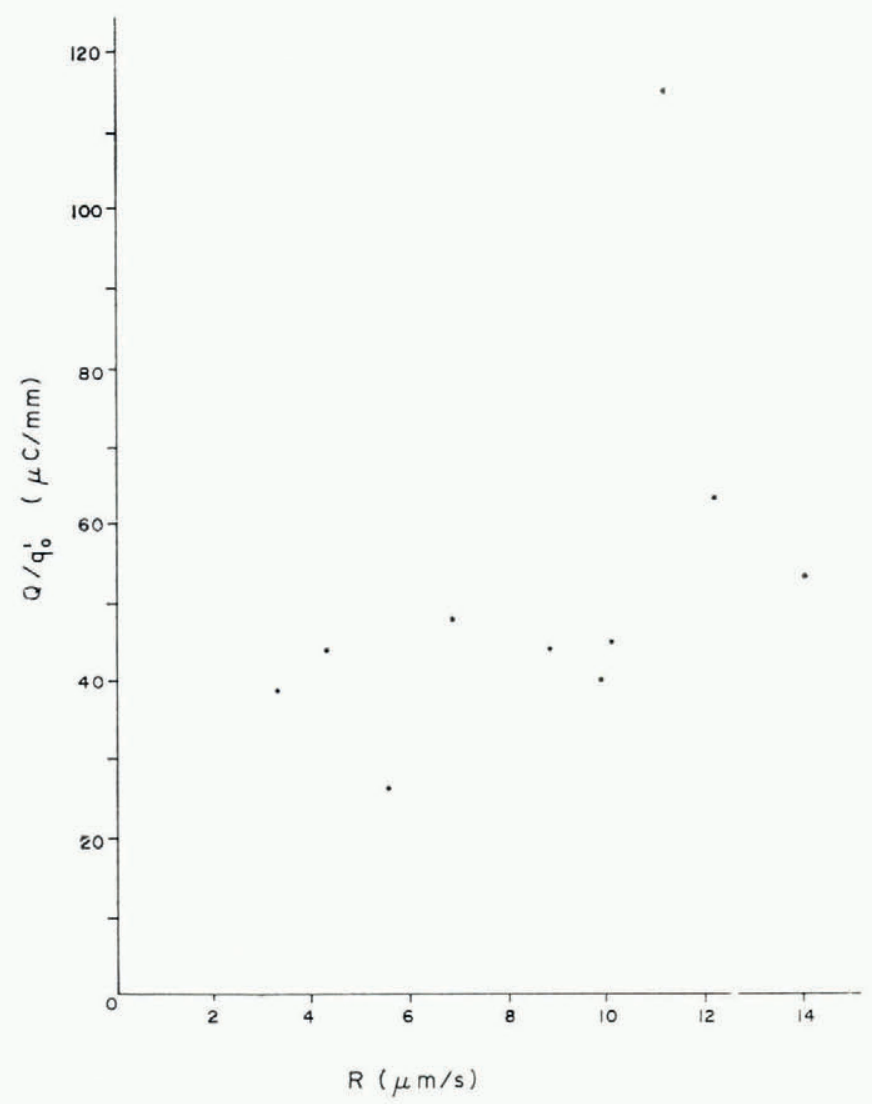

Fig. 8. The ratio of the charge transfer $Q$ to the interface thickness $q_{0}^{\prime}$, averaged over all concentrations, versus the freezing rate $R$.

As might be expected from Equation (6) and Figure 7, the ratio of the mean charge density listed in Table I to the charge generator parameter $I_{g}{ }^{\prime}$, also a charge density, has a nearly constant value of about $\frac{1}{3}$, as Figure 9 illustrates. This ratio indicates the fraction of separated charge which finds its way through the thickening layer of ice and the external shunt.

Figure 10 is a study of the relation between the charge generator parameter $I_{\mathrm{g}}{ }^{\prime}$ and the maximum freezing potential; according to Equation (6) this relation ought to be linear. In view of the clustering of the points in Figure ro, the best way of fitting a straight line seems to be the method of averages, choosing the line which passes through the origin and the centroid of some or all of the experimental points. The straight line drawn in the figure passes through 


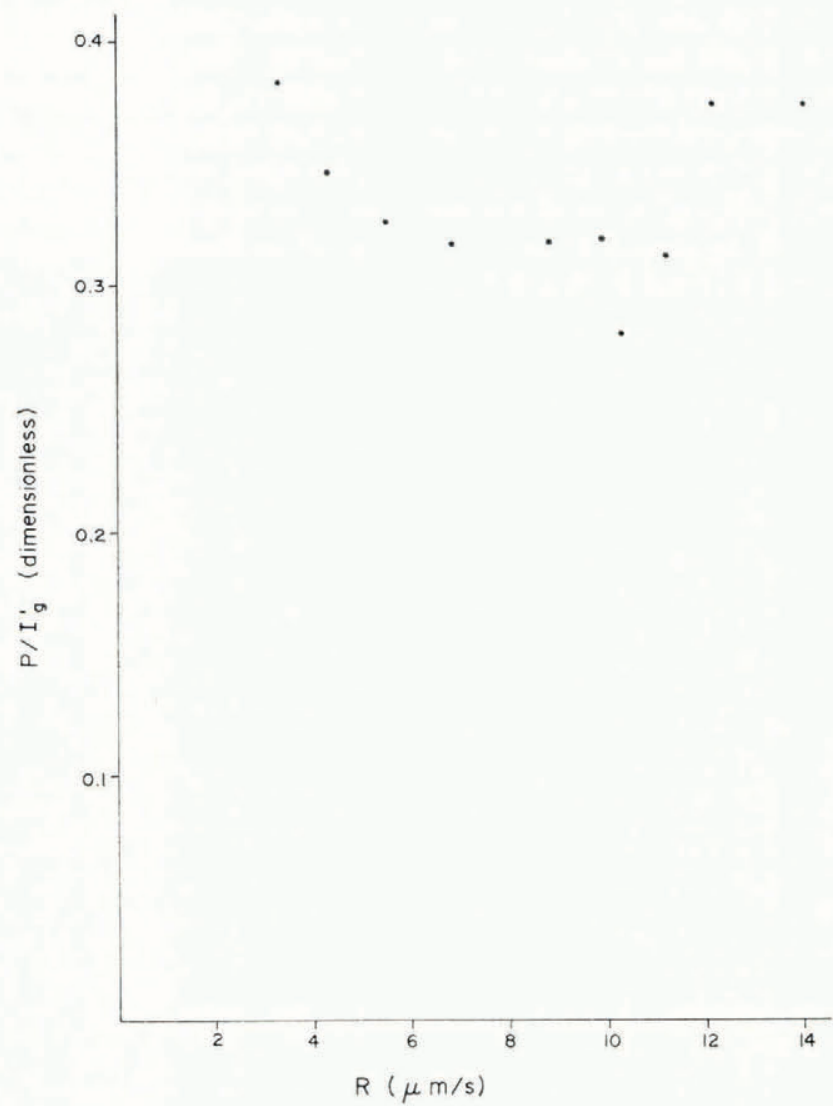

Fig. 9. The ratio of the charge transfer per unit volume of ice between the electrodes, $P$, to the charge generator pa:ameter $I_{\mathrm{g}}{ }^{\prime}$ averaged over all concentrations, vers:s the freezing rate $R$.

the centroid of all points except the three distant ones at I I.2 $\mu \mathrm{m} / \mathrm{s}$ and yields the Equation

$$
V_{\mathrm{m}}=0 . \mathrm{II}_{7} I_{\mathrm{g}}{ }^{\prime} \text {. }
$$

The coefficient of $I_{\mathrm{g}}{ }^{\prime}$ in (12) can be equated to $R_{\mathrm{i}} A R$ of Equation (6) to yield, after adjustment for the units of distance, area, and volume, the interface resistance

$$
R_{\mathrm{i}}=(22 \mathrm{I} / R) \times \mathrm{IO}^{6} \Omega,
$$

where the freezing rate $R$ remains expressed in $\mu \mathrm{m} / \mathrm{s}$. This relation, independent of concentration in the narrow concentration range studied, passes through the midst of the values obtained by the relation $R_{\mathrm{i}}=V_{\mathrm{m}} / I_{\mathrm{m}}$ and greatly smoothes out these values.

According to Equation (13), the interface resistance varied from $66.9 \mathrm{M} \Omega$ at $3.3 \mu \mathrm{m} / \mathrm{s}$ to $\mathrm{I} 5.8 \mathrm{M} \Omega$ at $\mathrm{I} 4 \mu \mathrm{m} / \mathrm{s}$ or, after dividing by the interface area of $53 \mathrm{I} \mathrm{mm}^{2}$, a resistance per unit area from $0.13 \mathrm{M} \Omega / \mathrm{mm}^{2}$ to $0.03 \mathrm{M} \Omega / \mathrm{mm}^{2}$ for the same freezing rates. These values are reasonably close to those reported for constant freezing rates by Gross (1967).

Gross ( 1965 , cf. his figure 3 ) found that the hydrogen ion content in the melted ice showed a maximum at some freezing rate, indicating that at that freezing rate the charge separation is maximum. It is possible that the peak in the parameter $K^{-}-K^{+}$is related to the peak in Gross's hydrogen-ion curve, but comparison is difficult because of the difference in growth conditions. 


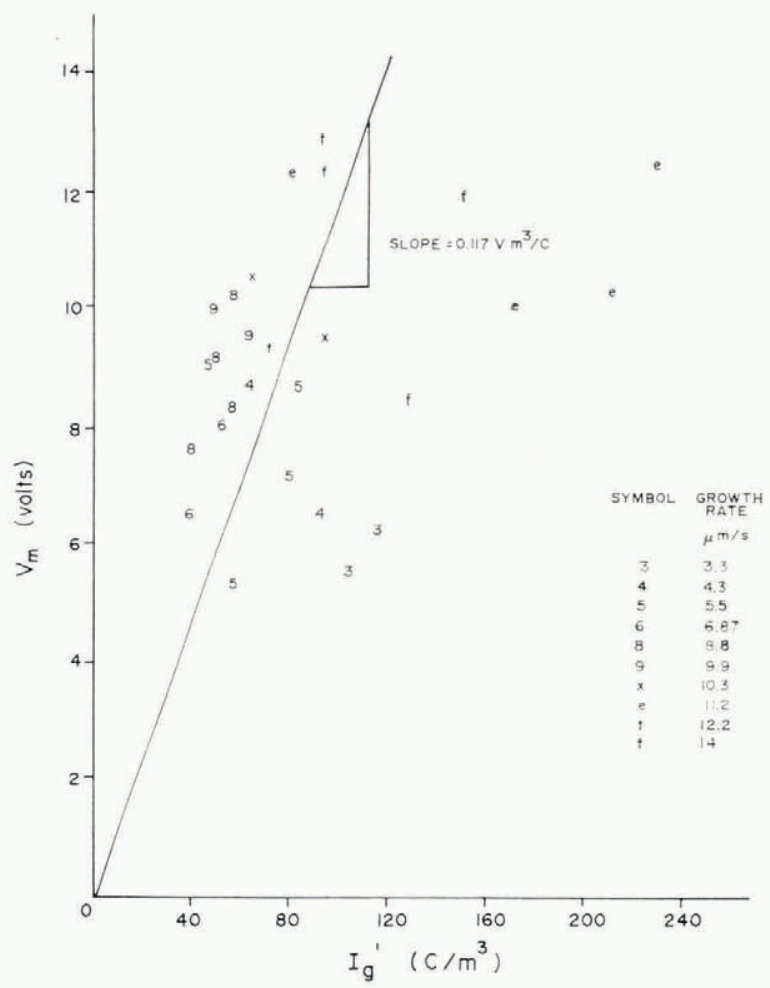

Fig. 10. Maximum freezing potential $V_{\mathrm{m}}$ versus the charge generator parameter $I_{\mathrm{g}}{ }^{\prime}$.

A semi-logarithmic plot of $K^{-}-K^{+}$versus $V_{\mathrm{m}}$ is shown in Figure I I. The points for the lower concentrations are irregular and represent best values rather than mean values at the slower growth rates. But for all concentrations there is a sharp rise after $8.8 \mu \mathrm{m} / \mathrm{s}$. An interesting feature is the nearly exponential relationship for the higher concentrations and slower growth rates. The relation might be expressed in the form

$$
K^{-}-K^{+}=\left(K^{-}-K^{+}\right) V_{=0} \exp \left(V_{\mathrm{m}} / V^{\prime}\right),
$$

where $V^{\prime}$ is a normalizing voltage found from the slope and $\left(K^{-}-K^{+}\right)_{V=0}$ is the intercept. For example, for $5 \times 10^{-5} \mathrm{~N}$ solutions, $V^{\prime} \approx 6 \mathrm{~V}$ and $\left(K^{-}-K^{+}\right)_{V=0} \approx 5 \times \mathrm{IO}^{-4}$. It is difficult to assign physical meanings to these values.

Between about 9 and $12 \mu \mathrm{m} / \mathrm{s}$ the increased values of discharge current, charge transfer, and the related parameter $\left(K^{-}-K^{+}\right)$indicate increased solute incorporation. Coincident with these greater values it was observed that during freezing at I I.2 $\mu \mathrm{m} / \mathrm{s}$ or faster the cloud in the ice became coarser, made up of slightly larger gas bubbles, and at the same time interior strains were such that the crystal always cracked or even shattered into many pieces while it was being slowly drawn out of the freezing bath for remelting.

These observations support Drost-Hansen's (1967) hypothesis that freezing potentials are to be explained by a selective incorporation of ions to relieve stresses in the ice, and Seidensticker and Longini's ( I969) suggestion that the Workman-Reynolds effect may depend on "interface states" which exist at the surface of frozen-in bubbles and at grain boundaries in the ice. 


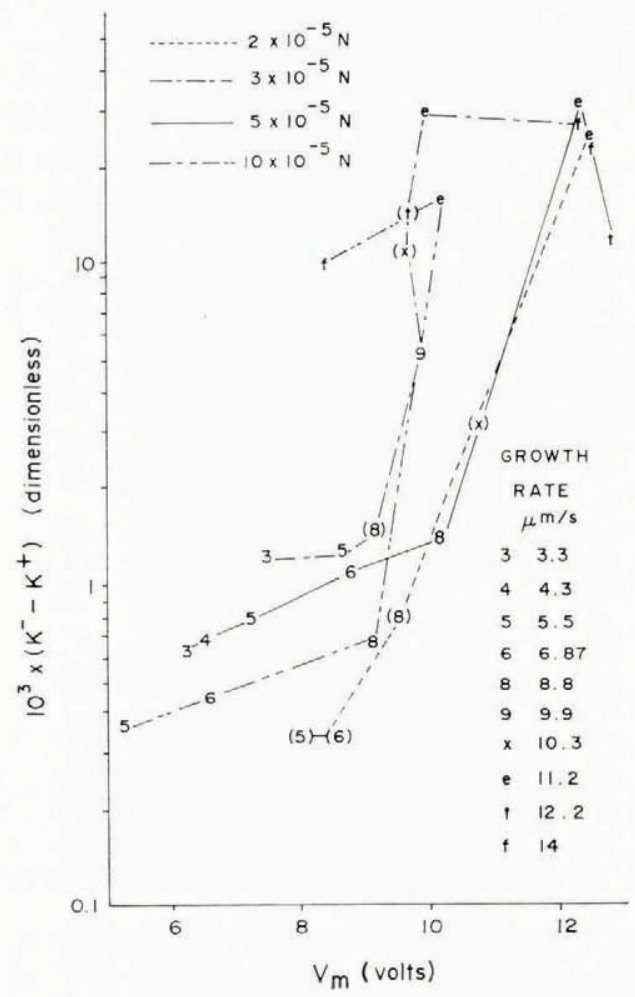

Fig. II. Plot of the difference between the ionic distribution coefficients $\left(K^{-}-K^{+}\right)$versus maximum freezing potential $V_{\mathrm{m}}$. Straight lines join points for the same concentration in order according to the growth rate.

(d) Comparison with steady-state results for $\mathrm{KCl}$ solutions

The comparisons with results of other experimenters which have been made in this article are affected by differences in the conditions of growth, and the effects of the differences are not properly known. The study of KCl solutions by Osterkamp and Weber (1970), however, was done with the same cell as the work reported here and under similar conditions. A detailed comparison of the two sets of results is presented in Table V. The effect of concentration is

TABl.e V. Comparison betWeen the REsults, under similar growth conditions, for KCl solutions by OSTERKAMP AND WEBER (1970) AND FOR KF SOLUTIONS AS PRESENTED IN THIS PAPER

Concentration used for this comparison, unless otherwise noted (Normality)

Peak freezing potential $V_{\mathrm{m}}(\mathrm{V})$,

and the growth rate at which it occurred $(\mu \mathrm{m} / \mathrm{s})$

Rate of freezing for the comparisons which follow $(\mu \mathrm{m} / \mathrm{s})$

Total charge passed through external shunt per unit mass of ice between the electrodes $(\mu \mathrm{C} / \mathrm{g})$

Concentration at the interface $\div$ bulk concentration, $C_{1}(\mathrm{o}) / C_{0}$

Apparent coefficient of diffusion $D\left(\mathrm{~mm}^{2} / \mathrm{s}\right)$

Apparent coefficient of distribution $K$ by Equation (2)

Apparent coefficient of distribution $K$ by Equation (3)

Interface capacitance $C_{\mathrm{i}}$ per unit area of interface $\left(\mathrm{pF} / \mathrm{mm}^{2}\right)$

Interface resistance $R_{1}$ per unit area of interface $\left(\Omega / \mathrm{mm}^{2}\right)$

$\mathrm{KCl}$

$\begin{array}{cc}2.2 \times 10^{-4} & 1 \times \mathrm{IO}^{-4} \\ 6.0 & 10 \\ 5.5 & 11.2 \\ 8.8 & 8.8 \\ 1.4 & 18\end{array}$

$$
\begin{array}{cc}
21.3 & 5.0 \\
3.2 \times 10^{-3} & 2.6 \times \mathrm{IO}^{-3} \\
0.047 & 0.20 \\
4 \times 10^{-3} & 10 \times 10^{-3 *} \\
3.6 & 0.43 \\
150 \times 10^{4} & 4.7 \times 10^{4}
\end{array}
$$


relatively small in Tables I to III, so that the differences in Table V can be attributed mainly to the solutes.

The ratio of the apparent coefficient of diffusion for $\mathrm{KF}$ to that for $\mathrm{KCl}$ in Table $\mathrm{V}$ is 0.82 . close to the ratio 0.80 of the values at infinite dilution for these coefficients, cited by Gross (1968). The fact that the fluoride ion is accepted into the ice more readily than the chloride ion means that the peak freezing potential, the charge transfer, and the coefficient of distribution will be greater for $\mathrm{KF}$ than for $\mathrm{KCl}$ solutions, as can be seen in the table.

\section{Conclusion}

This paper has presented the results of a first study of freezing potentials, currents, and the parameters of the LeFebre model for KF solutions at constant growth rates under steady-state conditions. It has compared the results for $\mathrm{KF}$ solutions with those reported for $\mathrm{KCl}$ solutions under similar conditions of growth. And it has pointed out several empirical relationships between the LeFebre parameters and the measurements of charge, relationships which tend to confirm LeFebre's theory, at least in part.

The authors wish to thank Dr G. W. Gross for helpful comments on a previous version of this manuscript.

MS. received I 2 February 1973 and in revised form 30 April 1973

\section{REFERENCES}

Costa Ribeiro, J. 1950. On the thermo-dielectric effect. Anais da Academia Brasileira de Ciencias, Tom. 22, No. 3, p. $325-48$.

Drost-Hansen, W. I967. The water-ice interface as seen from the liquid side. Journal of Colloid and Interface Science, Vol. 25, No. 2, p. $131-60$.

Gross, G. W. ${ }^{1965}$. The Workman-Reynolds effect and ionic transfer processes at the ice-solution interface. Journal of Geophysical Research, Vol. 70, No. 10, p. 2291-300.

Gross, G. W. 1967 . Ion distribution and phase-boundary potentials during the freezing of very dilute ionic solutions at uniform rates. Fournal of Colloid and Interface Science, Vol. 25, No. 2, p. 270-79.

Gross, G. W. 1968. Some effects of trace inorganics on the ice-water system. (In Gould, R. F., ed. Trace inorganics in water. Washington, D.C., American Chemical Society, p. 27-97. (Advances in Chemistry Series, No. 73.))

Jindal, B. K., and Tiller, W. A. 1972. Freezing potentials - effect of substrate on potential during the freezing of aqueous solutions at a uniform rate. Fournal of Colloid and Interface Science, Vol. 39, No. 2, p. 339-48.

Karagunis, G., and others. 1930. Zur Individualität der osmotischen Koeffizienten bei Alkalihalogeniden, [von] G. Karagunis, A. Hawkinson, Z. Damköhler. Zeitschrift für physikalische Chemie (Leipzig), Abt. A, Bd. I51, Ht. 5-6, p. 433-66. [Especially p. 462-64.]

LeFebre, V. 1967. The freezing potential effect. Fournal of Colloid and Interface Science, Vol. 25, No. 2, p. 263-69.

Levi, L., and Milman, O. 1966. Freezing potential of electrolyte solutions. Fournal of the Atmospheric Sciences, Vol. 23, No. 2, p. $182-86$.

Osterkamp, T. E., and Weber, A. H. 1970. Electrical phenomena accompanying the phase change of dilute $\mathrm{KCl}$ solutions into single crystals of ice. Fournal of Glaciology, Vol. 9, No. 56, p. 269-77.

Pinatti, D., and Mascarenhas, S. 1967. Electrical currents produced during the solidification of water (Costa Ribeiro effect). Journal of Applied Physics, Vol. 38, No. 6, p. 2648-52.

Pohl, R. G. 1954. Solute redistribution by recrystallization. Journal of Applied Physics, Vol. 25, No. 9, p. I $170-78$.

Seidensticker, R. G., and Longini, R. L. 1969. Impurity effects in ice. Journal of Chemical Physics, Vol. 50, No. I, p. $204^{-13}$.

Tiller, W. A., and others. 1953. The redistribution of solute atoms during the solidification of metals, by W. A. Tiller, K. A. Jackson, J. W. Rutter and B. Chalmers. Acta Metallurgica, Vol. I, No. 4, p. 428-37.

Workman, E. J., and Reynolds, S. E. 1950. Electrical phenomena occurring during the freezing of dilute aqueous solutions and their possible relationship to thunderstorm electricity. Physical Review, Ser. 2, Vol. 78, No. 3, p. 254-59. 